\title{
CNS Autoimmune Responses in BCMA- Deficient Mice Provide Insight for the Failure of Atacicept in MS
}

Gaurav Kumar, PhD, Zahra Maria, PhD, Uday Kohli, BA, Agnieshka Agasing, PhD, James L. Quinn, PhD, Rose M. Ko, PhD, Scott S. Zamvil, MD, PhD, and Robert C. Axtell, PhD

Neurol Neuroimmunol Neuroinflamm 2021;8:e973. doi:10.1212/NXI.0000000000000973

\section{Abstract}

\section{Objective}

B cells have emerged as a therapeutic target for MS. Anti-CD20 antibodies, which deplete B cells, are effective therapies for MS. However, atacicept (TACI-Fc), which blocks BAFF and APRIL and reduces B cells, unexpectedly exacerbates MS. We tested the hypothesis that B cell maturation antigen (BCMA), a receptor for BAFF and APRIL, plays a role in the paradoxical effects of anti-CD20 antibody and TACI-Fc using experimental autoimmune encephalomyelitis (EAE).

\section{Methods}

EAE was induced in wild-type $\left(\mathrm{BCMA}^{+/+}\right)$and $\mathrm{BCMA}$-deficient $\left(\mathrm{BCMA}^{-/-}\right)$mice with an immunization of rodent myelin oligodendrocyte glycoprotein $(\mathrm{MOG})_{35-55}$ peptide. Treatment with anti-CD20 antibody, TACI-Fc, and isotype controls was administered by intraperitoneal injections. CNS infiltration was evaluated by histology; immune cell phenotypes were evaluated by flow cytometry; MOG-specific antibodies were determined by ELISA. Mixed bone marrow chimeras and cell culture assays were used to identify the specific subsets of immune cells affected by BCMA deficiency.

\section{Results}

First, we found that $\mathrm{BCMA}^{-/-}$mice had more severe EAE compared with $\mathrm{BCMA}^{+/+}$mice and the increased disease was associated with elevated anti-MOG B-cell responses. Second, we found that anti-CD20 therapy attenuated EAE in $\mathrm{BCMA}^{-/-}$mice but not in $\mathrm{BCMA}^{+/+}$mice. Third, TACI-Fc attenuated EAE in $\mathrm{BCMA}^{+/+}$mice but not in $\mathrm{BCMA}^{-/-}$mice. Mixed bone marrow chimeric and cell culture experiments demonstrated that BCMA deficiency elevates inflammatory B-cell responses but inhibits inflammatory responses in macrophages.

\section{Conclusions}

BCMA has multifaceted roles during inflammation that affects therapeutic efficacies of antiCD20 and TACI-Fc in EAE. Our results from BCMA-deficient mice provide insights into the failure of atacicept in MS.

\author{
Correspondence \\ Dr. Axtell \\ bob-axtell@omrf.org
}




\section{Glossary}

APRIL $=$ a proliferation-inducing ligand $;$ BAFF $=\mathrm{B}$ cell activating factor BAFFR $=$ BAFF receptor BCMA $=$ B cell maturation antigen; Breg = regulatory B cell; CSM = class-switched memory; EAE = experimental autoimmune encephalomyelitis; $\mathbf{G C}=$ germinal center; IFN = interferon; Ig = immunoglobulin; IL = interleukin; MHCII = major histocompatibility complex class II; MOG = myelin oligodendrocyte glycoprotein; PBS = phosphate-buffered saline; PFA = paraformaldehyde; $\mathbf{T A C I}=$ transmembrane activator and calcium-modulating cyclophilin ligand interactor.

MS is a chronic disease of the CNS that is characterized by inflammation, demyelination, and neuronal damage. ${ }^{1} \mathrm{~T}$ cells, $\mathrm{B}$ cells, and myeloid cells mediate inflammation in MS. The importance of B cells in driving MS pathology was demonstrated with the successful clinical trials of B cell depletion with the anti-CD20 therapies, rituximab and ocrelizumab. ${ }^{2,3}$ However, atacicept (TACI-Fc), a recombinant soluble receptor that reduces B cell numbers by blocking both B cell activating factor (BAFF) and a proliferation-inducing ligand (APRIL), was reported to exacerbate disease activity in patients with MS. ${ }^{4}$ These opposing effects of anti-CD20 and
TACI-Fc therapies suggest that B cells have both inflammatory and anti-inflammatory effects in MS; however, the mechanism that drives these disparate results is currently unclear.

BAFF and APRIL are 2 cytokines that play fundamental roles in the development, differentiation, and function of B cells. ${ }^{5-8}$ BAFF and APRIL signal through the receptors BAFF receptor (BAFFR), transmembrane activator and calciummodulating cyclophilin ligand interactor (TACI), and B cell maturation antigen (BCMA). ${ }^{9-14}$ In experimental autoimmune

Figure 1 BCMA Deficiency Exacerbated EAE Disease Severity

A

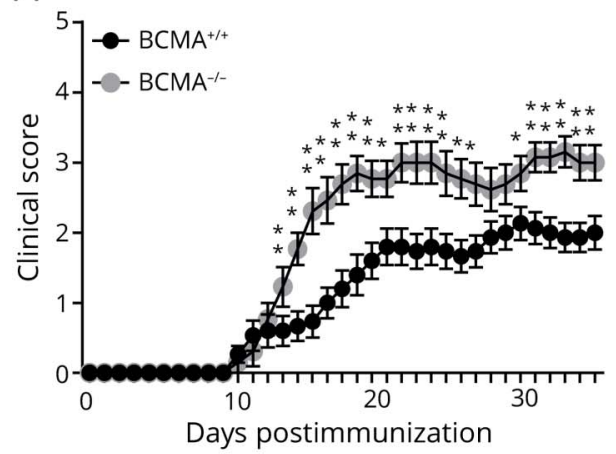

C

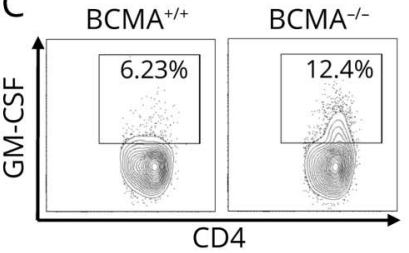

E

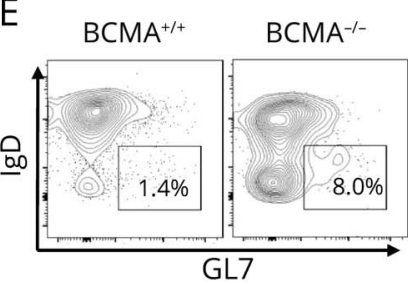

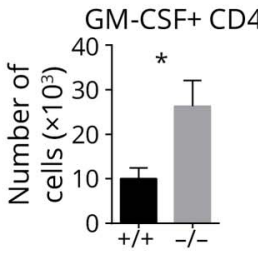

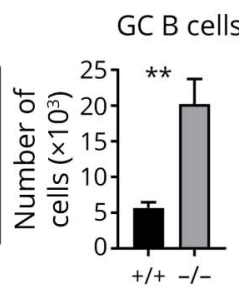

B
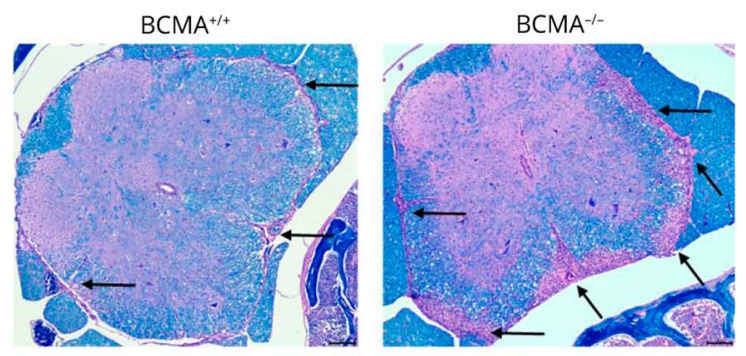

H\&E and Luxol Fast Blue stained spinal cord
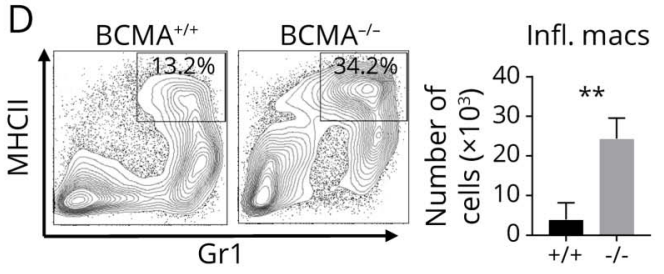

F
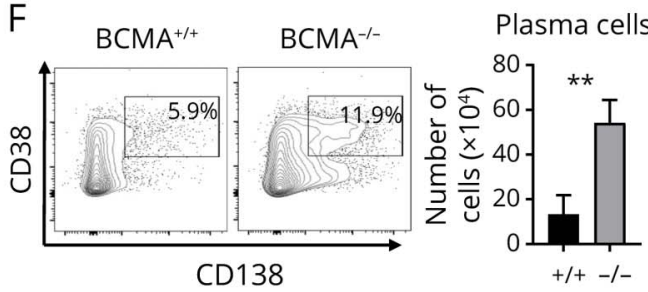

(A) EAE was induced in $\mathrm{BCMA}^{-/-}$mice and $\mathrm{BCMA}^{+/+}$mice and scored daily for disease severity. Data are pooled from 3 experiments ( $\mathrm{n}=15-18 /$ group). Nonparametric Mann-Whitney tests were used to determine statistical significance $(* p<0.05$ and $* \star p<0.01)$. (B) Representative spinal cord sections from $\mathrm{BCMA}^{+/+}$and $\mathrm{BCMA}^{-/-}$mice harvested at EAE day 15. Sections were stained with hematoxylin and eosin (H\&E) and Luxol fast blue, and arrows indicate lesions. Dark purple color indicates infiltrating cells, and blue color indicates the myelin. The presence of (C) GM-CSF ${ }^{+} \mathrm{CD} 4 \mathrm{~T}$ cells, (D) $\mathrm{MHCI}^{+} \mathrm{GR} 1^{+}$inflammatory macrophages, and (E) GL7 IgD ${ }^{-}$germinal center (GC) B cells and (F) CD138 ${ }^{+} \mathrm{CD}_{3} 8^{+}$plasma cells in the spinal cords of BCMA ${ }^{+/+}$and $B C M A^{-/-}$mice $(E A E$ day 15$)$ was measured by flow cytometry. Data are pooled from 2 experiments ( $n=5-10 /$ group). Error bars represent SEM, and Student $t$ tests were used to determine statistical significance $\left({ }^{\star} p<0.05\right.$ and $\left.{ }^{* \star} p<0.01\right)$. BCMA = B cell maturation antigen; EAE = experimental autoimmune encephalomyelitis; Ig = immunoglobulin; $\mathrm{MHCl}=$ major histocompatibility complex class II. 
encephalomyelitis (EAE) induced with myelin oligodendrocyte glycoprotein (MOG) ${ }_{35-55}$ peptide in mice, deficiencies in BAFFR, which cause a developmental blockade early in B cell development, elevate disease severity. ${ }^{12,15,16}$ This supports the theory that newly developed/immature B cells have regulatory properties in this model of EAE. However, BAFF and APRIL also have effects on $B$ cells at later stages of maturation and on non-B cells, which may also affect EAE. ${ }^{17-19}$

Unlike BAFFR deficiency, BCMA-deficient mice have no overt defects in the development and homeostasis of $\mathrm{B}$ cell populations, although it has been reported that there are effects on antigen presentation and the maintenance of longlived plasma cells. ${ }^{20,21}$ Previous studies have identified that BCMA has regulatory properties on inflammation in mouse models of lupus, where BCMA deficiency exacerbates lupuslike disease activity in mice. ${ }^{22}$ Currently, the function of BCMA in EAE is unclear. Furthermore, it is unknown whether BCMA influences the efficacy of therapies that target $\mathrm{B}$ cells. In this present study, we used $\mathrm{BCMA}^{-/-}$mice to explore the function of BCMA in EAE and test whether BCMA deficiency alters the efficacy of the anti-CD20 antibody and TACI-Fc in this disease model.

\section{Methods}

\section{Mice}

Dr. Loren D. Erickson (University of Virginia) provided $\mathrm{BCMA}^{-/-}$mice. These $\mathrm{BCMA}^{-/-}$were developed on C57BL/6J background by backcrossing for 12 generations, and then, the mice were genotyped using a panel of polymorphic microsatellite markers distributed across the entire genome to confirm $\mathrm{B} 6$ genetic background of $\mathrm{BCMA}^{-/-}$mice. ${ }^{20,22} \mathrm{C} 57 \mathrm{BL} / 6 \mathrm{~J}$ mice were used as wild-type $\left(\mathrm{BCMA}^{+/+}\right)$controls in all experiments. All mice were cohoused in a specific pathogen-free animal facility at Oklahoma Medical Research Foundation. All animal procedures were conducted in strict compliance with the guidelines and approved by the Institutional Animal Care and Use Committee.

\section{Induction and Assessment of EAE}

EAE was induced in 8-12-week-old female $\mathrm{BCMA}^{-/-}$mice along with age- and sex-matched $\mathrm{BCMA}^{+/+}$control mice. Mice were immunized with $150 \mu \mathrm{g} \mathrm{MOG}_{35-55}$ (Genemed Synthesis Inc., San Antonio, TX) emulsified in complete Freund adjuvant $(1.5 \mathrm{mg} / \mathrm{mL}$ heat-killed Mycobacterium tuberculosis), followed by an IP injection of $250 \mathrm{ng}$ Bordetella pertussis toxin (List Biological Labs, Inc., Campbell, CA) in phosphate-buffered saline (PBS) at the time of and 2 days after immunization. Clinical signs of EAE were assessed daily with $0-5$ scoring range: (1) loss of tail tone, (2) incomplete hind limb paralysis, (3) complete hind limb paralysis, (4) forelimb paralysis, and (5) moribund/dead.

\section{Histology}

Mice were perfused with $4 \%$ paraformaldehyde (PFA). Spinal cords were dissected from EAE mice, and the tissue was fixed overnight in $4 \%$ PFA and then in $20 \%$ sucrose and thereafter embedded in a single paraffin block. Five-micrometer-thick tissue sections were stained with hematoxylin and eosin and Luxol fast blue and imaged using a Nikon Eclipse E800M microscope.

\section{Flow Cytometry and Intracellular Staining}

Infiltrating cells were isolated from the brain and spinal cord of PBS-perfused mice. For this, CNS homogenates were incubated with collagenase and DNAse for 45 minutes at $37^{\circ} \mathrm{C}$, purified by a Percoll gradient, and washed with PBS. Singlecell suspensions were also made from spleen and draining lymph nodes after lysing red blood cells by ACK buffer. Cells were stained with the following reagents in various combinations: CD19 FITC, CD11b-PerCP-Cy5.5, immunoglobulin (Ig) D-PE, Ly-6G-Alexa Fluor 647, AA4.1- PerCP-Cy5.5, CD5-PECy7, CD38-FITC, CD19-PerCP-Cy5.5, CD138APC, CD138-PE, Ly-6C-FITC, Ly-6G-BV711, CD45.1BV711, CD45.2-BV711, interleukin (IL)-6-APC, GM-CSFFITC, Gr1-PE, major histocompatibility complex class II (MHCII)-PECy7, CD4-Pacific blue, B220-APC-efluor780, GL7-FITC, CD1d-APC, IgM-Pacific blue, CD21/35-APCefluor780, B220-PECy7, Streptavidin-FITC, CD267-APC, GL7-Pacific blue, interferon (IFN)- $\gamma$-Alexa488, IL-17A-PE, IL-10-PerCP-Cy5.5, CD4-PECy7, CD11b-PE, and Viability dye-efluor450, CD23-BV711 and CD95-BV711 and Peanut agglutinin-biotin (BioLegend, San Diego, CA; eBioscience, San Diego, CA; BD Biosciences, San Jose, CA; Vector Laboratories Inc., Burlingame, CA). For intracellular staining, cells were stimulated for 5 hours with phorbol 12-myristate 13-acetate (50 ng/mL; Sigma, St. Louis, MO), ionomycin (500 ng/mL; Sigma), and golgi stop (BD Biosciences) containing monensin in complete RPMI medium at $37^{\circ} \mathrm{C}$ under a $5 \% \mathrm{CO}_{2}$ atmosphere, stained, fixed, and permeabilized using buffers (BD Biosciences) and analyzed in flow cytometer. All cells were passed through LSRII flow cytometer, and data were analyzed using FlowJo software (Tree Star Inc., Ashland, OR).

\section{In Vitro $\mathrm{MOG}_{35-55}$ Recall Response}

For $\mathrm{MOG}_{35-55}$ recall response, spleens collected on day 10 from $\mathrm{BCMA}^{+/+}$and $\mathrm{BCMA}^{-/-}$EAE mice were processed into single-cell suspensions and cultured at $2.5 \times 10^{6}$ cells $/ \mathrm{mL}$ in complete RPMI 1640 with increasing $\mathrm{MOG}_{35-55}$ peptide concentration of $0,0.1,1$, and $10 \mu \mathrm{g} / \mathrm{mL}$ for 72 hours. IL-6, IL-10, IL-17, IFN- $\gamma$, IL-1 $\beta$, and GM-CSF cytokines from the culture supernatants were assessed by respective ELISA kits (eBiosciences). IL-6 in B cells, T helper cells, and myeloid cells were assessed by intracellular flow cytometry.

\section{Serum and Anti-MOG Ab Detection}

Mouse IgG total was measured in plasma with the mouse IgG total ELISA kit (eBioscience). Levels of anti-MOG Abs in mouse plasma were performed using indirect ELISAs. In brief, ELISA plates were coated with $10 \mu \mathrm{g} / \mathrm{mL} \mathrm{MOG}_{35-55}$ peptide. Plates were probed with $1 / 400$ dilutions of serum from 
individual mice, and reactive Abs were detected using peroxidase-conjugated goat and anti-mouse specific for IgG (Southern Biotech, Birmingham, AL) and developed with tetramethylbenzidine.

\section{Anti-CD20 and TACI-Fc Treatment}

The antibody against CD20 along with its isotype control was purchased from BioLegend. TACI-Fc was purchased from BioLegend and Human Fc-G1 from BioXcell. EAE was induced in $\mathrm{BCMA}^{+/+}$and $\mathrm{BCMA}^{-/-}$mice and treated with either anti-CD20, TACI-Fc, or controls with 2 doses of $250 \mu \mathrm{g}$ per mice on day 5 and day 10. An isotype control antibody or human Fc-G1 were used as treatment controls for anti-CD20 and TACI-Fc, respectively. Mice were monitored daily for clinical scores, and analysis was performed at the peak of disease (days 16-18).

\section{Flow Cytometry Sorting and Quantitative Real- Time PCR}

T cells, B cells, macrophages, and neutrophils were sorted from total splenic cells of EAE wild-type mice using BD FACS Aria cell sorting system (BD Biosciences). For quantitative PCR analysis, RNA was isolated using the RNeasy Micro Kit (Qiagen, Hilden, Germany), and cDNA was generated using the High Capacity cDNA Reverse Transcription Kit (Applied Biosystems, Foster City, CA). To detect BCMA transcript, following primers were used: forward 5' TGATCCAGTCCCTCATGG 3' and reverse 5' GAACTGGTCACGCTTGG 3'. As a housekeeping gene transcript, glyceraldehyde 3-phosphate dehydrogenase was used with the following primer sequences: forward $5^{\prime}$ CTCССАСТСТTCCACСТTCG $3^{\prime}$ and reverse $5^{\prime}$ CCACCACCCTGTTGCTGTAG 3'. Gene expression was assessed using MicroAmp Optical 96-well reaction plates and a 7900HT Fast Real-Time PCR System (Applied Biosystems). Data were analyzed using SDSv2.3 software (Applied Biosystems).

\section{Mixed Bone Marrow Chimeras}

Lethally irradiated $\mathrm{CD} 45.1+\mathrm{BCMA}^{+/+}$mice were rescued with mixed $5 \times 10^{6}$ bone marrow cells (50\% CD45.1 $\mathrm{BCMA}^{+/+}$and $50 \% \mathrm{CD} 45.2 \mathrm{BCMA}^{-/-}$). After 8 weeks of reconstitution, EAE was induced, and mice were killed at the peak of disease (day 16 or 17) for analysis.

\section{In Vitro Cell Stimulation With BAFF and APRIL}

Whole spleens from healthy mice were homogenized into single-cell suspensions, and CD11b+ cells and B cells were isolated by positive and negative selection, respectively (Miltenyi Biotec Inc., San Diego, CA). B cells were further sorted into discrete subsets using a BD FACS Aria cell sorting system (BD Biosciences).

Purified B cell subsets were stimulated with anti-CD40 antibody $(1 \mu \mathrm{g} / \mathrm{mL})+\mathrm{CpG}(0.02 \mu \mathrm{M} / \mathrm{mL})$ at a cell concentration of $2.5 \times 10^{6}$ cells $/ \mathrm{mL}$ along with BAFF $(25 \mathrm{ng} / \mathrm{mL})$ or APRIL $(50 \mathrm{ng} / \mathrm{mL})$ in complete RPMI medium at $37^{\circ} \mathrm{C}$ under a $5 \% \mathrm{CO}_{2}$ for 72 hours. $\mathrm{CD} 11 \mathrm{~b}+$ myeloid cells were stimulated with lipopolysaccharides $(100 \mathrm{ng} / \mathrm{mL})$ at a cell concentration of $2.5 \times 10^{6}$ cells $/ \mathrm{mL}$ along with BAFF $(25 \mathrm{ng} / \mathrm{mL})$ or APRIL $(50 \mathrm{ng} / \mathrm{mL})$ in complete RPMI medium at $37^{\circ} \mathrm{C}$ under a $5 \% \mathrm{CO}_{2}$ for 72 hours. ELISAs detected levels of IL-6, IL-10, GM-CSF, and IL-12p40 in the cell culture supernatants (eBiosciences).

\section{Statistical Analysis}

Statistics were determined using Prism software v6.0 (GraphPad Software, La Jolla, CA). Data are presented as mean \pm SEM, and statistical significance was determined using a 2-tailed Mann-Whitney test, Student $t$ test, or analysis of variance when more than 2 groups were analyzed. For all data sets, differences were considered statistically significant for $p<$ or $=0.05$.

\section{Data Availability}

Engineered mouse strains described in this article can be made available through a material transfer agreement. TACIFc and anti-CD20 antibodies are available for purchase from BioLegend. All data associated with this study are present in the article or in the supplementary materials.

\section{Results}

\section{BCMA-Deficient Mice Have Exacerbated EAE}

To evaluate the role of BCMA in EAE, we induced disease with $\mathrm{MOG}_{35-55}$ in $\mathrm{BCMA}$-deficient $\left(\mathrm{BCMA}^{-/-}\right)$mice and BCMA-sufficient $\left(\mathrm{BCMA}^{+/+}\right)$control mice. $\mathrm{BCMA}^{-/-}$mice showed increased EAE severity in comparison to $\mathrm{BCMA}^{+/+}$ mice (figure $1 \mathrm{~A}$ ). At day 15 postinduction of EAE, histologic analysis of spinal cords revealed increased cellular infiltration and increased demyelination in the $\mathrm{BCMA}^{-/-}$mice compared with $\mathrm{BCMA}^{+/+}$mice (figure $1 \mathrm{~B}$ and figure e-1, links. lww.com/NXI/A434). We specifically found increased numbers of GM-CSF ${ }^{+} \mathrm{T}$ helper cells (figure 1C), $\mathrm{IL}_{-1} 7^{+} \mathrm{T}$ helper cells (figure e-2A, links.lww.com/NXI/A435), inflammatory macrophages (figure 1D), germinal center (GC) $B$ cells (figure $1 \mathrm{E}$ ), and plasma cell (figure $1 \mathrm{~F}$ ) infiltrating the spinal cords of the $\mathrm{BCMA}^{-/-}$mice compared with $\mathrm{BCMA}^{+/+}$ mice. Brains from these mice had similar results. The $\mathrm{BCMA}^{-/-}$mice had increased infiltration of $\mathrm{IL}-17^{+} \mathrm{T}$ helper cells, GM-CSF ${ }^{+} \mathrm{T}$ helper cells, inflammatory macrophages, and plasma cells compared with the $\mathrm{BCMA}^{+/+}$mice (figure e-2, B-I). We next compared the MOG-specific cytokine production from $\mathrm{BCMA}^{-/-}$and $\mathrm{BCMA}^{+/+}$mice from the spleen cells 10 days after induction of EAE. We found that spleen cells from $\mathrm{BCMA}^{-/-}$mice secreted significantly higher levels of the inflammatory cytokines, GM-CSF (figure e-3A, links.lww.com/NXI/A436), IL-6 (figure e-3B), IFN- $\gamma$ (figure e-3C), and IL-1 $\beta$ (figure e-3D) in response to increasing concentration of $\mathrm{MOG}_{35-55}$ compared with spleens from $\mathrm{BCMA}^{+/+}$mice. Surprisingly, there were no differences in secretion of the inflammatory IL-17A (figure e-3E). We also found no differences in the secretion of the antiinflammatory cytokine IL-10 (figure e-3F). Using 
A
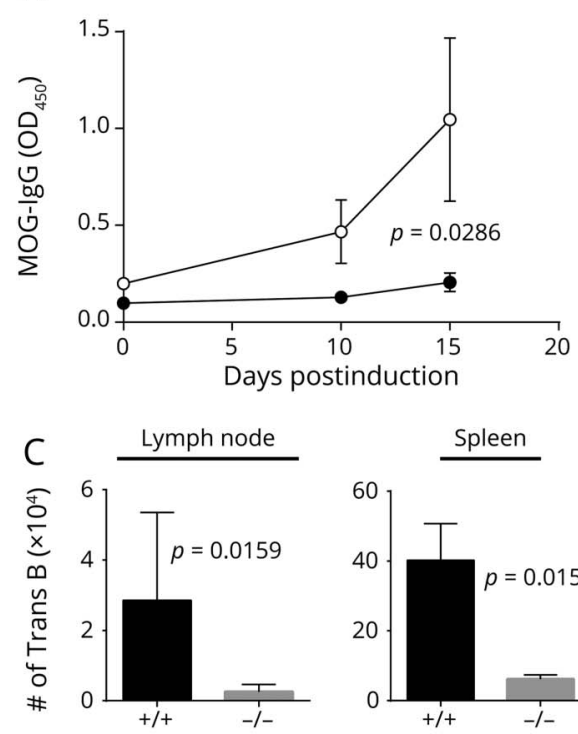

E
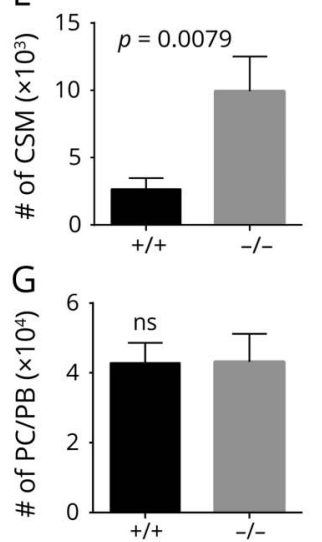
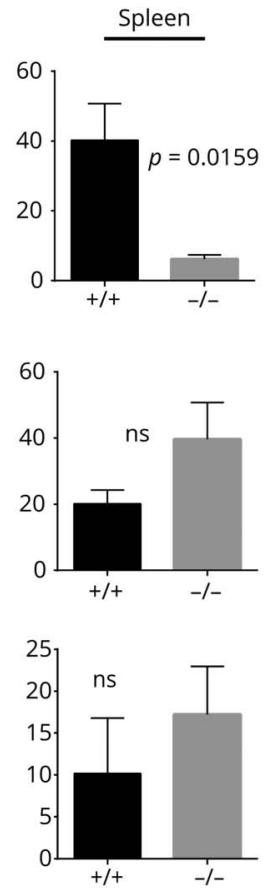

\section{B}

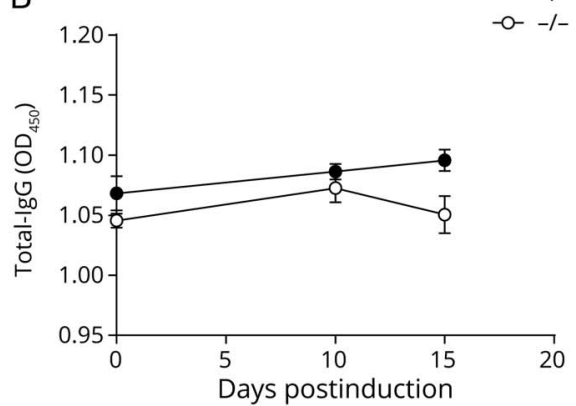

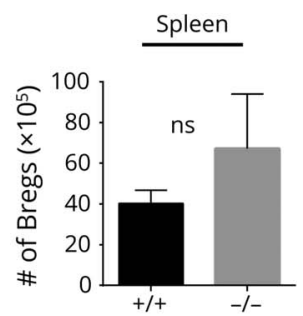

$\mathrm{F}$

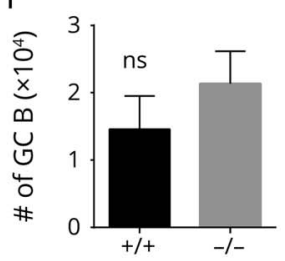

$\mathrm{H}$

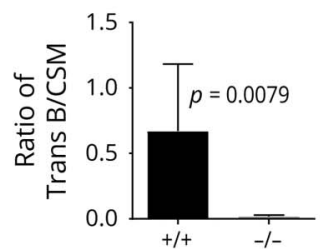

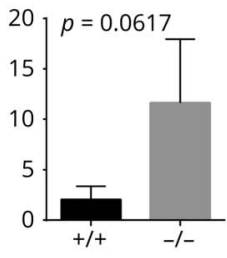

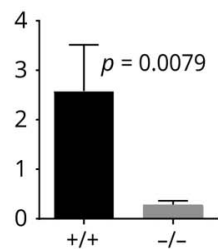

Serum was collected from $\mathrm{BCMA}^{+/+}$ and $\mathrm{BCMA}^{-/-}$mice on EAE days 0,10 , and 15 , and $(A)$ MOG IgG and (B) total-IgG were measured by ELISA ( $n=$ 5 per group). At EAE day 15, absolute numbers of (C) transitional (Trans) B cells, (D) regulatory B cells (Bregs), (E) class-switched memory (CSM) B cells, (F) germinal center (GC) B cells, and (G) plasma cells/plasmablasts (PC/PB) in the lymph node and spleen cells from $\mathrm{BCMA}^{+/+}$and $\mathrm{BCMA}^{-/-}$mice were measured by flow cytometry. (H) The ratio of trans/CSM B cells from lymph nodes and spleens from $\mathrm{BCMA}^{+/+}$and $\mathrm{BCMA}^{-1-}$ mice was determined. Data are pooled from 2 experiments $(n=$ $10 /$ group). ${ }^{+/+}$represents $\mathrm{BCMA}^{+/+}$, and ${ }^{-1-}$ represents $\mathrm{BCMA}^{-/-}$. Error bars represent SEM, and Student $t$ tests were used to determine statistical significance. $p<0.05$ is statistically significant. BCMA $=B$ cell maturation antigen; $E A E$ = experimental autoimmune encephalomyelitis; $\mid \mathrm{g}=$ immunoglobulin; MOG = myelin oligodendrocyte glycoprotein. intracellular flow cytometry, we identified that B cells and $\mathrm{T}$ cells but not macrophages were contributing to the elevated IL-6 in the $\mathrm{BCMA}^{--}$cultures (figure e-3, G-I).

\section{BCMA-Deficient Mice Have Increased B Cell Responses During EAE}

Previous studies demonstrated that BCMA deficiency alters $\mathrm{B}$ cell responses in experimental lupus models. ${ }^{22}$ Therefore, we assessed whether humoral response to MOG is altered in the $\mathrm{BCMA}^{-/-}$mice compared with $\mathrm{BCMA}^{+/+}$mice during EAE. We found that by day 15 postinduction of EAE, $\mathrm{BCMA}^{-/-}$mice had significantly higher amounts of antiMOG IgG in sera compared with $\mathrm{BCMA}^{+/+}$mice (figure $2 \mathrm{~A}$ ). Total-IgG in the sera was not significantly different in $\mathrm{BCMA}^{+/+}$and $\mathrm{BCMA}^{-/-}$mice at any time throughout disease (figure 2B).

We next compared $\mathrm{BCMA}^{+/+}$mice and $\mathrm{BCMA}^{-/-}$mice for alterations in the distribution of $\mathrm{B}$ cell populations that would be indicative of a strong B cell response during EAE. Specifically, we assessed the absolute numbers of transitional (Trans) B cells, $\mathrm{CD5}^{+}$regulatory B cells (Bregs), classswitched memory (CSM) B cells, GC B cells subsets, and plasmablasts/plasma cells (figure e-4, links.lww.com/NXI/ A437) in both lymph nodes and spleens in healthy mice and in mice with EAE (days 16-18). In healthy mice, we observed no significant differences in any subset of $B$ cells in the spleens or lymph nodes from $\mathrm{BCMA}^{+/}$compared with $\mathrm{BCMA}^{-/-}$ mice (figure e-5, links.lww.com/NXI/A438). However, in mice with EAE, there were striking differences in B cell subsets. We found that Trans B cells were significantly reduced in both lymph nodes and spleens of $\mathrm{BCMA}^{-/-}$compared with $\mathrm{BCMA}^{+/+}$mice (figure 2C). $\mathrm{CD}^{+}$Breg numbers were also decreased in lymph nodes compared with $\mathrm{BCMA}^{+/+}$(figure 2D); however, this difference was not observed in spleens. We observed a significant increase of CSM B cells in lymph nodes of $\mathrm{BCMA}^{-1-}$ (figure $2 \mathrm{E}$ ) but not in spleens. We saw no difference in numbers of GC B cells in lymph nodes or spleens 


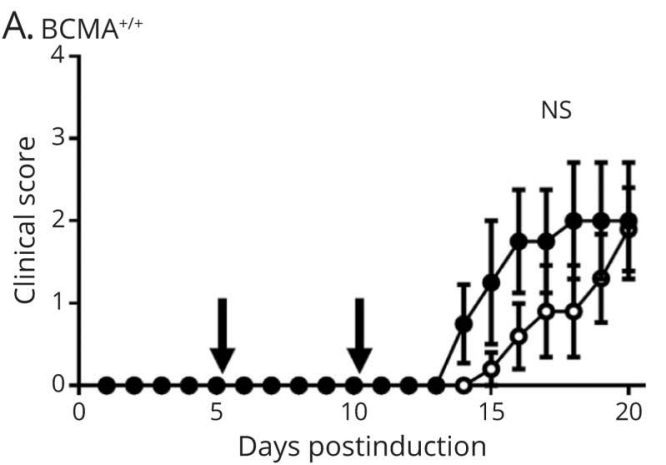

B

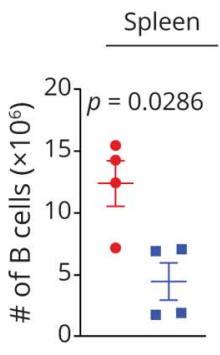

E. $\mathrm{BCMA}^{+/+}$

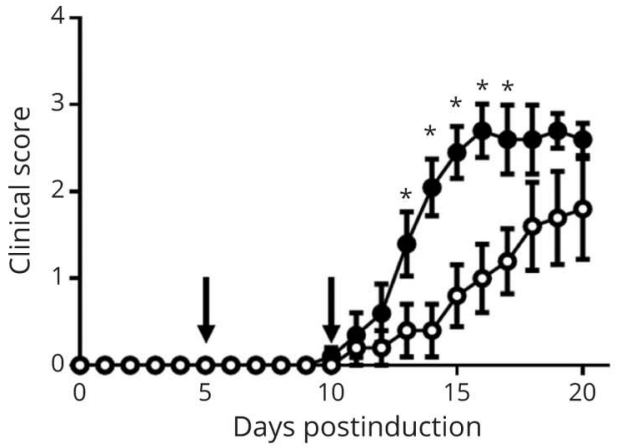

F
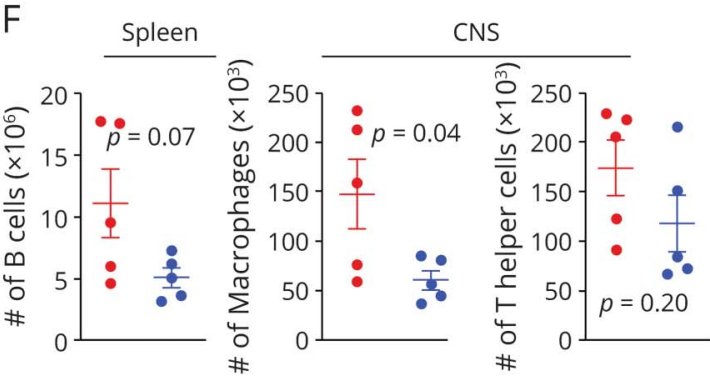

C. BC

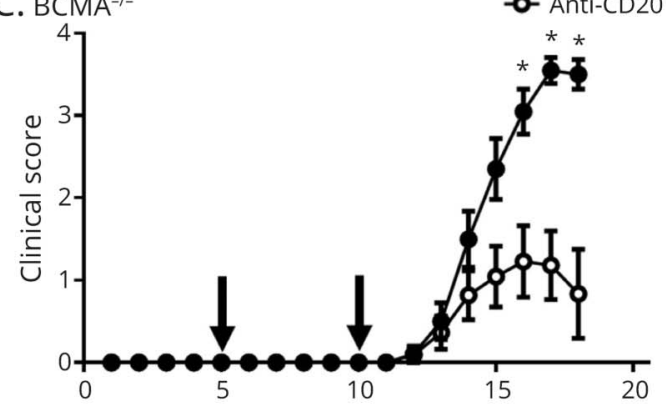

Days postinduction

$\rightarrow$ Iso

- Anti-CD20

D

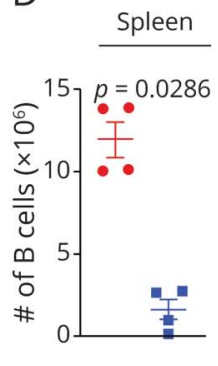

G. $\mathrm{BCMA}^{-1-}$
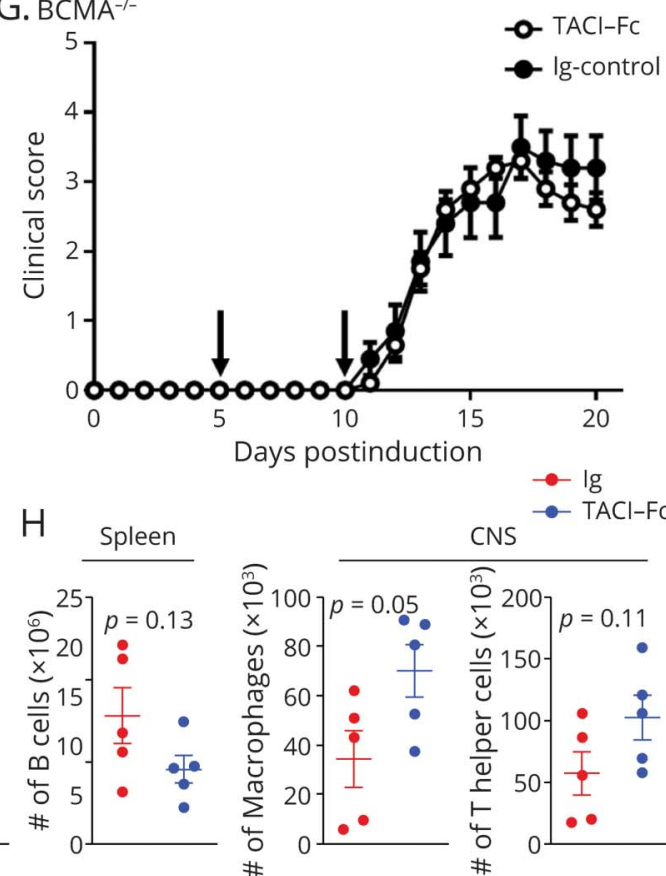

Days postinduction
CNS

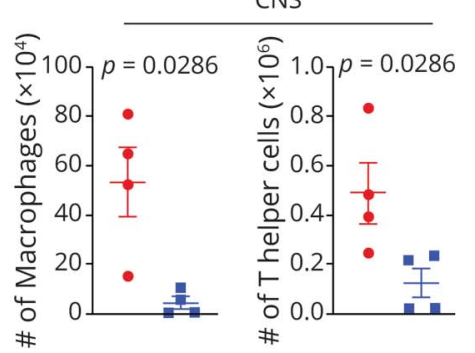

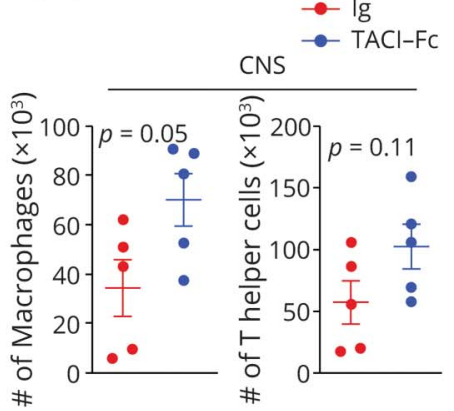

(A) $\mathrm{BCMA}^{+/+}$mice were treated with either isotype control or anti-CD20 on day 5 and day 10 postinduction of EAE and scored daily. Arrows indicate the treatment days. Data are pooled from 2 experiments $(n=10 /$ group). (B) At the peak of the disease, numbers of splenic $B$ cells, spinal cord-infiltrating macrophages, and Thelper cells from isotype control and anti-CD20 treated $B C M A^{+++}$mice were assessed by flow cytometry $(n=4 / g r o u p)$. (C) BCMA ${ }^{-/-}$mice were treated with either isotype control or anti-CD20 on day 5 and day 10 postinduction of EAE and scored daily. Arrows indicate the treatment days. Data are pooled from 2 experiments ( $n=10 /$ group). (D) At the peak of the disease, numbers of $B$ cells in the spleen and numbers of macrophages and Thelper cells in the spinal cord from isotype control and anti-CD20-treated BCMA ${ }^{-1-}$ mice were assessed by flow cytometry $(n=4 / g r o u p)$. Error bars represent SEM. Nonparametric Mann-Whitney tests were used for EAE scores $\left({ }^{*} p<0.05\right)$. Student $t$ tests were used for the flow cytometric data. TACI-Fc treatment ameliorates EAE in $\mathrm{BCMA}^{+/+}$mice but not in $\mathrm{BCMA}^{-/-}$mice. (E) $\mathrm{BCMA}^{+/+}$mice were treated with Ig control or TACl-Fc on day 5 and day 10 postinduction of EAE and scored daily. Arrows indicate the treatment days. Data are pooled from 2 experiments ( $n=10 /$ group). (F) At the peak of the disease, numbers of splenic $B$ cells, spinal cord-infiltrating macrophages, and Thelper cells from control and TACI-Fc treated BCMA ${ }^{++}$mice were assessed by flow cytometry ( $\left.n=5 / g r o u p\right)$. (G) BCMA ${ }^{-1-}$ mice were treated with Ig control or TACI-Fc on day 5 and day 10 postinduction of EAE and scored daily. Arrows indicate the treatment days. Data are pooled from 2 experiments. $\mathrm{N}=10 / \mathrm{group}$. $(\mathrm{H})$ At the peak of the disease, numbers of $\mathrm{B}$ cells in spleen and numbers of macrophages and T helper cells in the spinal cord of control and TACI-Fc-treated $\mathrm{BCMA}^{-1-}$ mice were assessed by flow cytometry ( $\mathrm{n}=5$ /group). Error bars represent SEM. Nonparametric MannWhitney tests were used for EAE scores $\left({ }^{\star} p<0.05\right)$. Student $t$ tests were used for the flow cytometric data. BCMA = B cell maturation antigen; EAE = experimental autoimmune encephalomyelitis. 


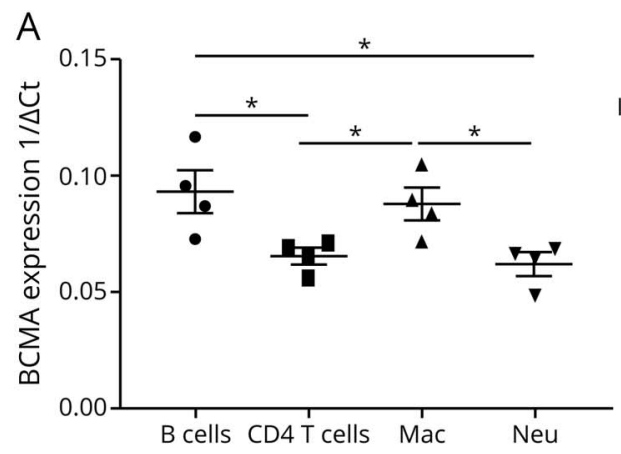

\section{B}

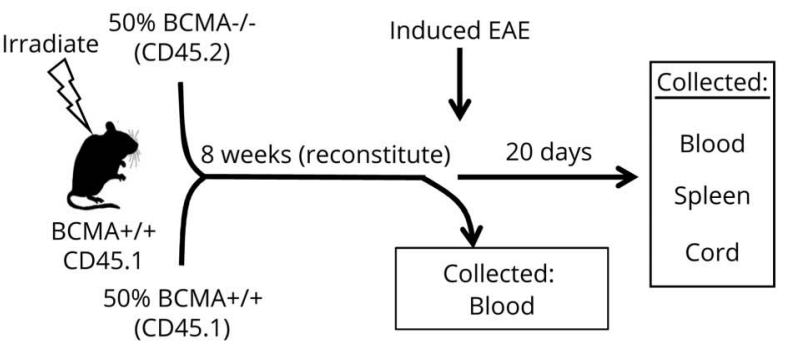

\section{Pre-EAE induction: Blood}

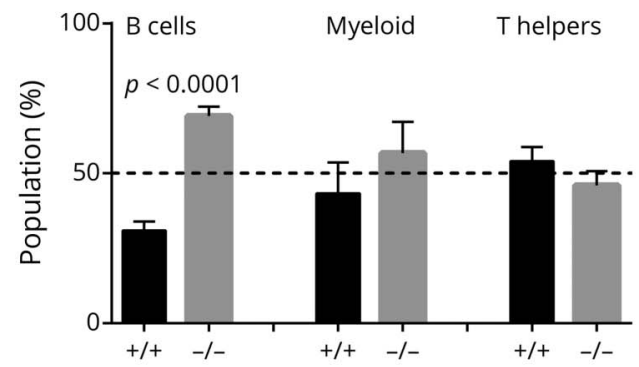

\section{EAE: Blood}

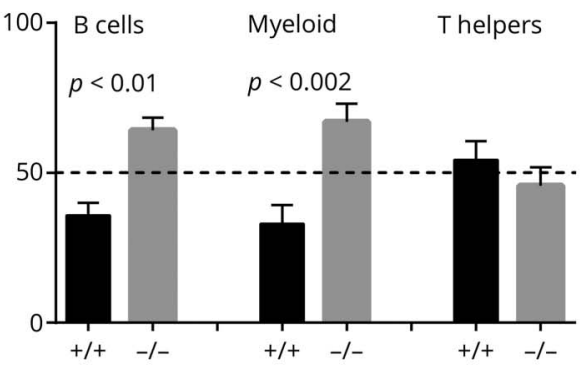

\section{E. EAE: Spleen}

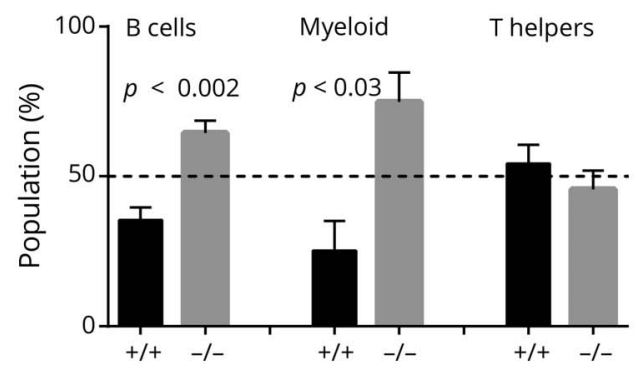

F. EAE: Spleen B-cells

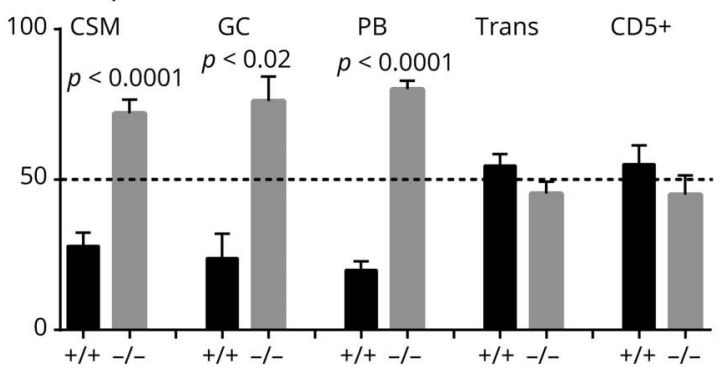

G. EAE: Spinal cord

H. EAE: Cord myeloid cells
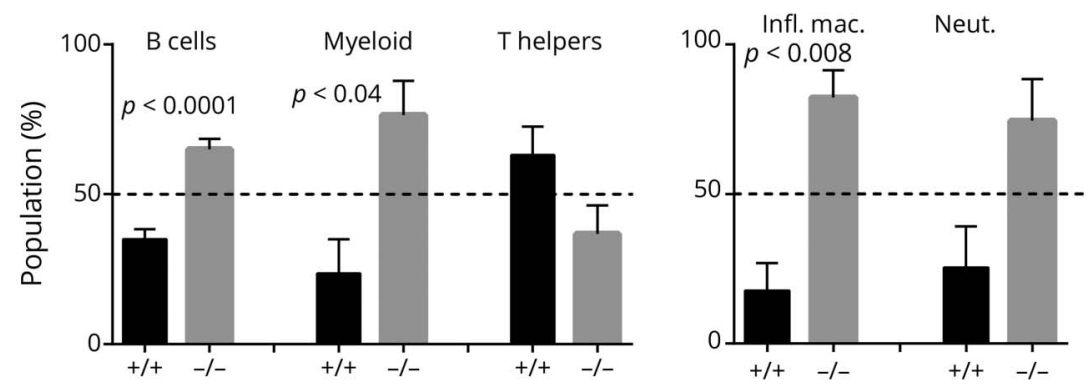

(A) B cells, CD4 T cells, macrophages, and neutrophils were FACS sorted from $B C M A^{+/+}$mice with $E A E$, and quantitative real-time $P C R$ was performed for $B C M A$ expression. Data represent 1/ACt of BCMA expression on B cells, CD4 T cells, macrophages, and neutrophils ( $n=4 /$ group). Analysis of variance was used for statistics $\left.{ }^{\star} p<0.05\right)$. (B) Bone marrow chimeric strategy. Lethally irradiated CD45.1 BCMA ${ }^{+++}$mice were transplanted with equal number of bone marrow cells from CD45.1 $\mathrm{BCMA}^{+/+}$and CD45.2 BCMA ${ }^{-/-}(n=5)$. Eight weeks after transplantation, EAE was induced. The percentage of $B$ cells, myeloid cells, and Thelper cells derived from donor $\mathrm{BCMA}^{+/+}$and $\mathrm{BCMA}^{-/-}$cells in were assessed in (C) the blood before inducing EAE and in the (D) blood and (E) spleens 20 days after EAE induction. (F) The percentage of class-switched memory (CSM) B cells, germinal center (GC) B cells, plasmablasts (PB), transitional (Trans) B cells, regulatory $\mathrm{B}$ cells (Bregs) derived from donor $\mathrm{BCMA}^{+/+}$, and $\mathrm{BCMA}^{-/}$cells from spleens during EAE. (G) The percentage of $\mathrm{B}$ cells, myeloid cells, and Thelper cells derived from donor $\mathrm{BCMA}^{+/+}$and $\mathrm{BCMA}^{-/-}$cells that have infiltrated the spinal cord during $\mathrm{EAE}$. $(\mathrm{H})$ Percentage of inflammatory macrophages and neutrophils derived from donor $\mathrm{BCMA}^{+/+}$and $\mathrm{BCMA}^{-/-}$cells that have infiltrated the spinal cord of EAE mice. Error bars represent SEM, and Student $t$ tests were used to determine statistical significance. $B C M A$ = B cell maturation antigen; EAE = experimental autoimmune encephalomyelitis.

(figure 2F). Finally, we found no alterations of plasmablasts or plasma cells in $\mathrm{BCMA}^{-/-}$compared with $\mathrm{BCMA}^{+/+}$mice (figure $2 \mathrm{G}$ ). These data strongly suggest that during EAE, BCMA deficiency acts as brake on the maturation and differentiation of $\mathrm{B}$ cells during an immune response. This was revealed when we calculated the ratio of Trans B cells/CSM $\mathrm{B}$ cells in both $\mathrm{BCMA}^{-/-}$and $\mathrm{BCMA}^{+/+}$, where there is a significant decrease in the ratio of Trans B cells/CSM B cells 
in $\mathrm{BCMA}^{-/-}$mice compared with the $\mathrm{BCMA}^{+/+}$mice in both spleens and lymph nodes during EAE (figure $2 \mathrm{H}$ ).

These data demonstrate that there are altered B cell populations in $\mathrm{BCMA}^{-/-}$mice during EAE. The most striking result is the reduction of Trans $B$ cells with a maintenance or increase in CSM B cells, GC B cells, and plasmablasts/plasma cells. Our data suggest that BCMA acts to maintain the regulatory transitional B cell population and attenuate downstream B cell responses, which leads to reduced autoimmune inflammation.

\section{Anti-CD20 Treatment Is Effective in BCMA- Deficient Mice}

Our data show an association with increased $\mathrm{B}$ cell activity with increased disease severity in the $\mathrm{BCMA}^{-/-}$mice. To directly determine whether $\mathrm{B}$ cells from the $\mathrm{BCMA}^{-/-}$mice have inflammatory function in EAE, we compared the effects anti-CD20 treatment had on EAE in $\mathrm{BCMA}^{-/-}$mice and in $\mathrm{BCMA}^{+/+}$mice. We treated mice with anti-CD20 or an isotype control on day 5 and day 10 of EAE, a treatment regimen that has been shown to have no clinical effects in wild-type mice. ${ }^{23}$ As previously reported, anti-CD20 treatment had no significant effect on EAE severity in the $\mathrm{BCMA}^{+/+}$mice (figure 3A). The anti-CD20 treatment decreased B cells numbers in the spleen and spinal cord of $\mathrm{BCMA}^{+/+}$mice but had no effect on the infiltration of macrophages or $\mathrm{T}$ helper cells into the spinal cord (figure $3 \mathrm{~B}$ and figure e-6, links.lww. com/NXI/A439). In contrast to $\mathrm{BCMA}^{+/+}$mice, this treatment strategy significantly reduced disease severity in $\mathrm{BCMA}^{-/-}$mice (figure $3 \mathrm{C}$ ). The anti-CD20 treatment decreased $\mathrm{B}$ cells numbers in the spleen and spinal cord of $\mathrm{BCMA}^{-/-}$mice and decreased the infiltration of macrophages and $\mathrm{T}$ helper cells into the spinal cord (figure $3 \mathrm{D}$ and figure e-6).

These data demonstrate that $\mathrm{B}$ cells have an inflammatory role during EAE in $\mathrm{BCMA}^{-/-}$mice and have the potential to drive disease by modulating the functions of inflammatory macrophages and $\mathrm{T}$ helper cells and facilitating their infiltration into the CNS.

\section{TACI-Fc Treatment Requires BCMA to Ameliorate EAE}

BAFF and APRIL are essential for the development and function of $\mathrm{B}$ cells and blocking BAFF and APRIL signaling reduces $B$ cell numbers in both human and mice. ${ }^{24-26}$ However, a large clinical trial demonstrated that pharmacologic blockade of BAFF and APRIL with TACI-Fc increased inflammatory disease activity in patients with MS (IMP28063, ClinicalTrials.gov identifier: NCT00642902). As BCMA is a receptor of BAFF and APRIL, we assessed the effect of TACIFc treatment on the severity of EAE in both $\mathrm{BCMA}^{+/+}$and $\mathrm{BCMA}^{-/-}$mice. Surprisingly, we found that TACI-Fc treatment, dosed at day 5 and day 10, significantly ameliorates EAE in $\mathrm{BCMA}^{+/+}$mice (figure $3 \mathrm{E}$ ). This treatment reduced CNSinfiltrating macrophages but not splenic $B$ cell numbers or
CNS-infiltrating $\mathrm{CD}^{+} \mathrm{T}$ cells in the $\mathrm{BCMA}^{+/+}$mice (figure $3 \mathrm{~F})$. In contrast, TACI-Fc treatment had no clinical effects in $\mathrm{BCMA}^{-/-}$mice (figure 3G). This treatment had no effects on splenic B cell numbers or CNS-infiltrating $\mathrm{CD}^{+}{ }^{+} \mathrm{T}$ cells, but did elevate the CNS-infiltrating macrophages in the $\mathrm{BCMA}^{-/}$ - mice (figure $3 \mathrm{H}$ ).

The reduction in disease in $\mathrm{BCMA}^{+/+}$mice by TACI-Fc treatment was quite surprising considering that anti-CD20 treatment had no effect on disease in these mice. This led us to speculate that BAFF and APRIL signaling may have inflammatory effects on non-B cells.

\section{BCMA Directly Affects B Cells and Macrophages in EAE}

The disparate efficacies of anti-CD20 and TACI-Fc in the $\mathrm{BCMA}^{+/+}$and $\mathrm{BCMA}^{-/-}$mice suggest that $\mathrm{BCMA}$ is expressed by other immune cells apart from $\mathrm{B}$ cells during EAE. Therefore, we assessed the expression of BCMA on FACS-sorted B cells, T cells, macrophages, and neutrophils from C57BL/6 mice with EAE. We found that $\mathrm{B}$ cells and macrophages showed elevated expression of BCMA compared with $\mathrm{CD}^{+} \mathrm{T}$ cells and neutrophils (figure 4A).

These data demonstrate that $\mathrm{B}$ cells and macrophages express BCMA. Therefore, we sought to determine the cellular responses directly affected by BCMA deficiency during EAE. To do this, we generated mixed bone marrow chimeric mice by rescuing lethally irradiated $\mathrm{CD} 45.1 \mathrm{BCMA}^{+/+}$recipient mice by transplanting equal number of bone marrow cells from $\mathrm{CD} 45.1 \mathrm{BCMA}^{+/+}$and CD45.2 $\mathrm{BCMA}^{-/-}$(figure 4B). Eight weeks after bone marrow transplantation, we induced $\mathrm{EAE}$ in these mice.

Before EAE induction, we collected blood to assess the ratio of $\mathrm{BCMA}^{+/+}\left(\mathrm{CD}^{4} 5.1^{+}\right)$and $\mathrm{BCMA}^{-/-}\left(\mathrm{CD}^{2} 5.2^{+}\right)$in $B$ cell, myeloid cell, and $T$ helper cell populations. We found that $\mathrm{BCMA}^{-/-}$comprised a significantly greater proportion of $\mathrm{B}$ cells but not $\mathrm{CD} 11 \mathrm{~b}^{+}$myeloid cells or $\mathrm{CD} 4^{+} \mathrm{T}$ helper cells (figure $4 \mathrm{C}$ ). In contrast, at the peak of EAE, we found that both $\mathrm{B}$ cells and $\mathrm{CD} 11 \mathrm{~b}^{+}$myeloid populations were skewed toward $\mathrm{BCMA}^{-/-}$but not $\mathrm{CD} 4^{+} \mathrm{T}$ cells in the blood (figure 4D). Similarly, in the spleens, B cells and myeloid cells, but not $\mathrm{T}$ cells, were predominantly $\mathrm{BCMA}^{-/-}$ (figure 4E).

We next determined the specific splenic B cell subsets affected by BCMA deficiency. We found that CSM B cells, GC $B$ cells, and plasmablasts all had significantly greater proportion of $\mathrm{BCMA}^{-/-}$compared with $\mathrm{BCMA}^{+/+}$in spleens (figure 4F). Of interest, this competitive advantage was not extended to the Trans $\mathrm{B}$ cells and $\mathrm{CD}^{+}$Bregs from spleens as their percentage of $\mathrm{BCMA}^{-/-}$and $\mathrm{BCMA}^{+/+}$was not significantly different (figure 4F).

Similar to peripheral tissues, we also found that B cells and myeloid cells, but not $\mathrm{T}$ cells, had an increased ratio of 
A

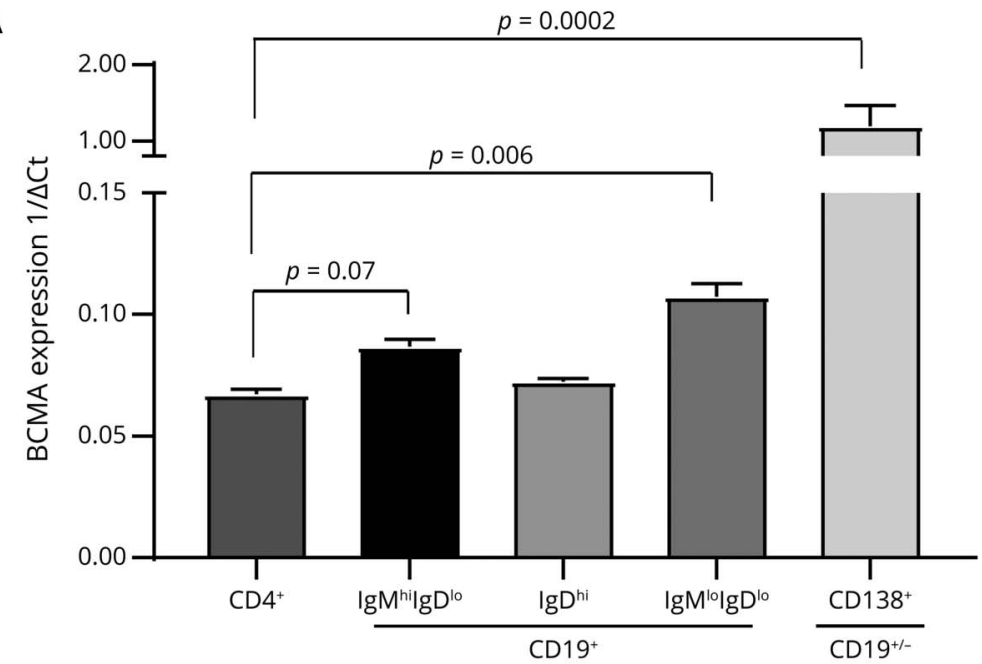

B

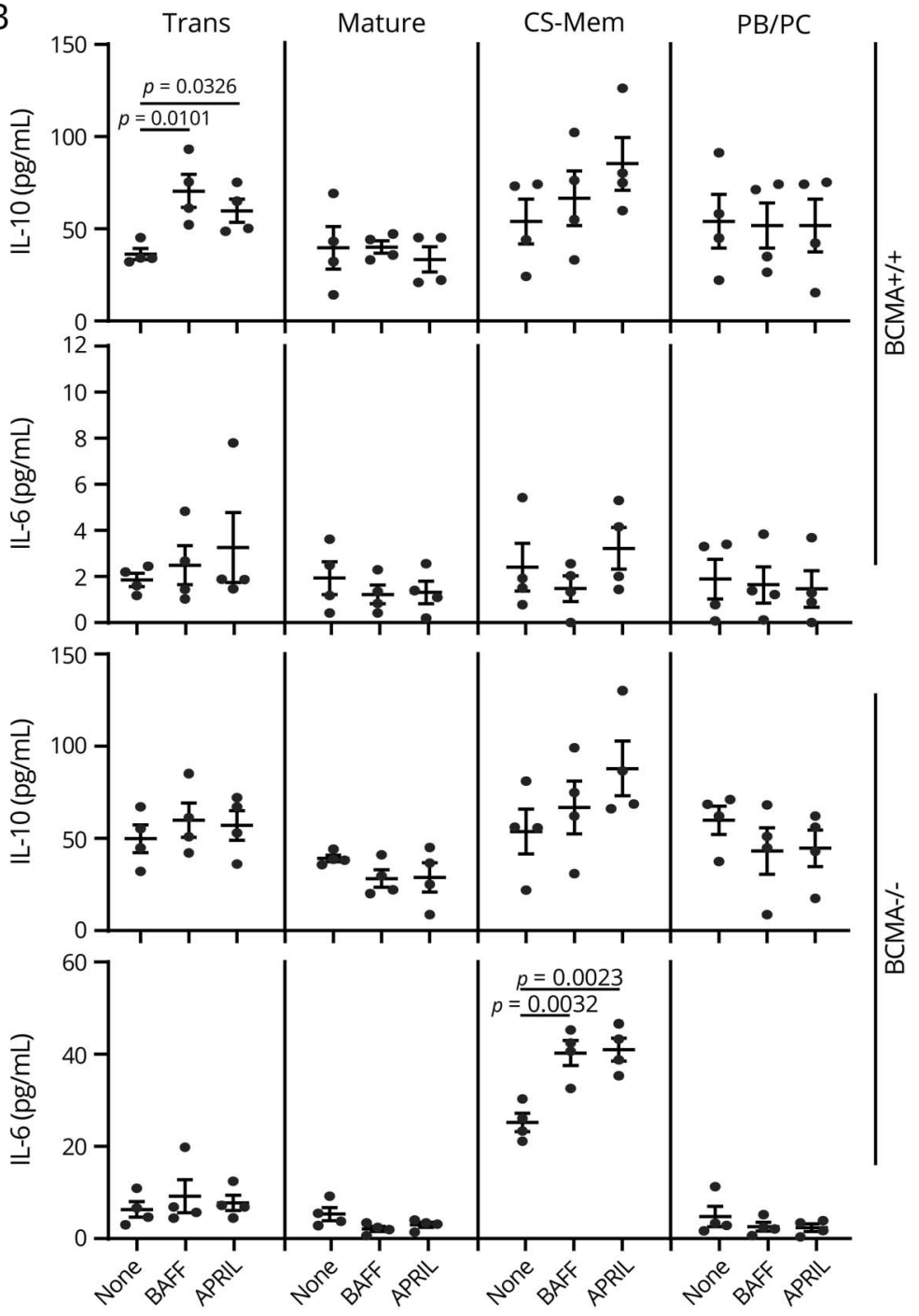

(A) Four different $\mathrm{B}$ cell subsets, $\mathrm{CD}^{1} 9^{+} \mid \mathrm{IM}^{\mathrm{hi}} \mathrm{gD} \mathrm{D}^{\text {lo }}$ (transitional/regulatory $\mathrm{B}$ cells), CD19+1gD ${ }^{\text {hi }}$ (mature B cells), $\mathrm{CD}^{1} 9^{+} \mathrm{IgM}^{1 \mathrm{o}} \mathrm{IgD}^{\mathrm{lo}}$ (class-switched memory B cells), CD19 ${ }^{+/}$ $\mathrm{CD} 138^{+}$(plasmablasts/plasma cells), and $\mathrm{CD}^{+} \mathrm{T}$ cells were FACS sorted from $\mathrm{BCMA}^{+/+}$mice with $\mathrm{EAE}$, and quantitative real-time PCR was performed for BCMA expression. The data represent $1 / \Delta C$ t of BCMA expression ( $n=4$ /group). Error bars represent SEM, and analysis of variance was used to determine statistical differences. (B) Trans (transitional/ regulatory) $B$ cells, mature $B$ cells, CS-Mem (class-switched memory B cells), and PB/PC (plasmablasts/plasma cells) were FACS sorted from $\mathrm{BCMA}^{+/+}$and $\mathrm{BCMA}^{-/-}$mice and stimulated with anti-CD40 in the presence or absence of BAFF and APRIL. To get enough numbers of smaller B cell subsets, 5 spleens were pooled together. After 72 hours, cell culture supernatants were collected, and IL- 6 and IL-10 secretion was measured by ELISA. Error bars represent SEM, and Student $t$ tests were used to determine statistical significance. $p<0.05$ was considered to be statistically significant. $\mathrm{APRIL}=\mathrm{a}$ proliferation-inducing ligand; $\mathrm{BAFF}=\mathrm{B}$ cell-activating factor; $\mathrm{BCMA}=\mathrm{B}$ cell maturation antigen; $\mathrm{EAE}$ $=$ experimental autoimmune encephalomyelitis; IL = interleukin.
$\mathrm{BCMA}^{-/-}$to $\mathrm{BCMA}^{+/+}$in the spinal cords of these chimeric mice (figure 4G). In the myeloid cell compartment, we observed that inflammatory macrophages $\left(\mathrm{GR}^{+} \mathrm{MHCII}^{+}\right)$, but not neutrophils $\left(\mathrm{GR}^{+} \mathrm{MHCII}^{-}\right)$, were significantly skewed toward $\mathrm{BCMA}^{-/-}$(figure $4 \mathrm{H}$ ). Taken together, these data demonstrate that BCMA deficiency has intrinsic effects on the 

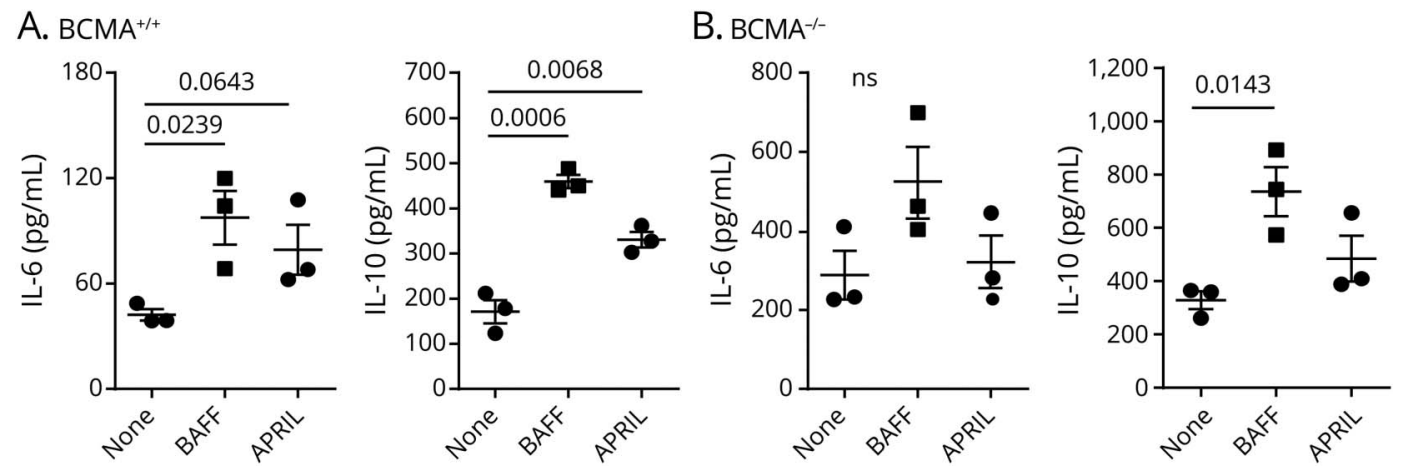

$\mathrm{CD} 11 \mathrm{~b}^{+}$myeloid cells were MACS sorted from healthy (A) $\mathrm{BCMA}^{+/+}$and (B) $\mathrm{BCMA}^{-/-}$mice and stimulated with lipopolysaccharides in the presence or absence of BAFF or APRIL ( $n=3 /$ group). After 72 hours, supernatants were collected, and IL- 6 and IL-10 secretion was measured by ELISA. Error bars represent SEM, and Student $t$ tests were used to determine statistical significance. $p<0.05$ was considered to be statistically significant. APRIL $=$ a proliferation-inducing ligand; $\mathrm{BAFF}=\mathrm{B}$ cell activating factor; $\mathrm{BCMA}=\mathrm{B}$ cell maturation antigen; $\mathrm{EAE}=$ experimental autoimmune encephalomyelitis; $\mathrm{IL}=$ interleukin.

$B$ cell and macrophage responses during EAE but has no effect on $\mathrm{T}$ helper cell function.

\section{BCMA Regulates Cytokine Production in Discrete B Cell Subsets}

We next assessed the expression of BCMA on different $B$ cell subsets, including plasma cells. We sorted 4 different $B$ cell subsets from the spleens of C57BL/6 mice with EAE by FACS cell sorting. Because of the rarity of certain transitional and regulatory population, we used the following broad gating scheme to determine BCMA transcript expression in B cell subsets. We sorted cells in the $\mathrm{CD} 138^{+} \mathrm{CD} 19^{+/-}$gate that contains plasma cells/ plasmablasts, the $\mathrm{CD} 19^{+} \mathrm{IgD}^{\text {hi }}$ gate that contains mature $\mathrm{B}$ cells, the $\mathrm{CD} 19^{+} \mathrm{IgM}^{\mathrm{hi}} \operatorname{IgD}{ }^{\text {lo }}$ gate that contains Trans $\mathrm{B}$ cells/Bregs, and the $\mathrm{CD} 19^{+} \mathrm{IgM}{ }^{\mathrm{lo}} \mathrm{IgD}{ }^{\mathrm{lo}}$ gate that contains CSM B cells (figure e-7, links.lww.com/NXI/A440). We found that plasma cells/plasmablasts and CSM B cells expressed significantly higher levels of BCMA compared with $\mathrm{CD}^{+} \mathrm{T}$ cells (figure $5 \mathrm{~A}$ ). Trans $\mathrm{B}$ cells and mature $B$ cells did not express BCMA transcript at significantly higher levels to $\mathrm{CD}^{+} \mathrm{T}$ cells (figure 5A).

We next evaluated the effects of in vitro BAFF and APRIL stimulation on these sorted $B$ cell subsets. In cells isolated from $\mathrm{BCMA}^{+/+}$mice, we found that BAFF or APRIL stimulation elevates IL-10 production by Trans B cells while having no effect on mature B cells, CSM B cells, and plasmablasts/plasma cells (figure 5B). BAFF or APRIL stimulation had no effect on IL-6 production by $B$ cell subsets from $\mathrm{BCMA}^{+/+}$mice (figure 5B). In $\mathrm{BCMA}^{-/-}$ mice, BAFF or APRIL stimulation had no effect on IL-10 production by any $B$ cell subsets but did elevate the production of IL-6 by CSM B cells (figure 5B). We also assessed the secretion of GM-CSF and IL-12p40 on stimulation with BAFF and APRIL and found no differences in $\mathrm{BCMA}^{+/+}$and $\mathrm{BCMA}^{-/-} \mathrm{B}$ cells (data not shown).

\section{BCMA Regulates Cytokine Function in Myeloid Cells}

The disparate results from the anti-CD20 and TACI-Fc treatment experiment described above provide compelling in vivo evidence that BAFF and/or APRIL stimulation through BCMA is modulating the inflammatory effects of myeloid cells. To understand the cellular mechanisms behind these findings, we designed in vitro assays to compare the effects BAFF and APRIL stimulations have on myeloid cells from $\mathrm{BCMA}^{+/+}$and $\mathrm{BCMA}^{-/-}$mice. Specifically, we stimulated purified $\mathrm{CD} 11 \mathrm{~b}^{+}$ myeloid cells with either BAFF or APRIL and assessed the secretion of the proinflammatory $\mathrm{IL}-6$ and anti-inflammatory IL-10.

We found that $\mathrm{CD} 11 \mathrm{~b}^{+}$cells from $\mathrm{BCMA}^{+/+}$mice had elevated production of both $\mathrm{IL}-6$ and $\mathrm{IL}-10$ when stimulated with BAFF or APRIL (figure 6A). In $\mathrm{BCMA}^{-/-} \mathrm{CD}_{11 \mathrm{~b}^{+}}$cells, BAFF and APRIL had no significant effect on $\mathrm{IL}-6$ production, but BAFF continued to drive $\mathrm{IL}-10$ production (figure $6 \mathrm{~B}$ ). We also assessed the secretion of IL-12p40 on stimulation with BAFF and APRIL and found no differences in $\mathrm{BCMA}^{+/+}$and $\mathrm{BCMA}^{-/-} \mathrm{CD}_{11 \mathrm{~b}}^{+}$ cells (data not shown).

\section{Discussion}

Until now, no studies have described the function of BCMA deficiency in neuroinflammation. Initially, BCMA was found to be highly expressed by plasma cells and functioned to maintain the survival of antibody producing plasma cells in bone marrow. ${ }^{27}$ Other studies have shown that GC B cells and memory B cells express $\mathrm{BCMA}$, and this receptor regulates the generation of $\mathrm{B}$ cell responses. ${ }^{17,28}$ In lupus prone mice, BCMA deficiency leads to elevated autoantibody responses and increased morbidity and mortality demonstrating that BCMA regulates autoreactive $\mathrm{B}$ cell responses. ${ }^{22}$ Recent studies suggested that BAFF and APRIL have functional effects on non-B-lineage cell types including myeloid 
cells, astrocytes, and neurons; yet, the function of BCMA in these non-B cell types is unknown. ${ }^{18}$

In this study, we have provided evidence for 2 novel mechanisms of BCMA in neuroinflammation. The first mechanism we have identified is that BAFF and APRIL signaling through $\mathrm{BCMA}$ has a $\mathrm{B}$ cell-intrinsic, anti-inflammatory effect on EAE disease. We find that $\mathrm{BCMA}^{-/-}$mice have exacerbated disease that is associated with increased B cell responses to myelin antigens, which in turn elevates the pathogenicity of the $\mathrm{T}$ helper cells within the CNS. In bone marrow chimeras, BCMA deficiency provides a competitive advantage for the development of inflammatory B cell populations (including GC, memory, and plasmablast B cells). During in vitro stimulations, BAFF and APRIL drive the secretion of the anti-inflammatory IL-10 in $\mathrm{BCMA}^{+/+} \mathrm{B}$ cells and conversely drive the inflammatory IL-6 in $\mathrm{BCMA}^{-/-} \mathrm{B}$ cells. Most convincingly, we found that anti-CD20 therapy attenuates EAE in $\mathrm{BCMA}^{-/-}$ mice but not $\mathrm{BCMA}^{+/+}$mice. These data are in accordance with EAE studies from BAFFR-deficient mice. This study shows that deficiency in BAFF signaling exacerbated EAE, which is similar to our results with BCMA-deficient mice. ${ }^{16}$ Of interest, $\mathrm{BAFF}^{-/-}$and $\mathrm{BAFFR}^{-/-}$mice both have deficiencies in mature $\mathrm{B}$ cell development, which is not a defect in $\mathrm{BCMA}^{-/-}$ mice. ${ }^{15,20}$ Therefore, the data from $\mathrm{BCMA}^{-/-}$mice suggest that BAFF and/or APRIL also act downstream of the early developmental checkpoints of $B$ cells and act as a brake on the development and function of inflammatory B cell populations.

The second mechanism is that BCMA has inflammatory effects on myeloid cells during EAE. We detected BCMA gene expression in macrophages. We find that BAFF and APRIL stimulation elevates the secretion of the inflammatory cytokine IL-6 in $\mathrm{BCMA}^{+/+}$macrophages but not in $\mathrm{BCMA}^{-/-}$macrophages. Finally, we find that TACI-Fc effectively reduces EAE in $\mathrm{BCMA}^{+/+}$mice but not in $\mathrm{BCMA}^{-/-}$mice and that the reduction of disease in $\mathrm{BCMA}^{+/+}$mice is correlated with a reduction in infiltrating inflammatory macrophages but not $\mathrm{T}$ cells or B cells. These data are in accordance with a recent publication showing that BAFF-deficient mice crossed to B cell-deficient mice have lowered EAE severity. ${ }^{19}$ Our study provides compelling evidence that the proinflammatory effect of BAFF is specifically through BCMA on macrophages.

The observations from the clinical trials of anti-CD20 and TACI-Fc revealed that there is still a major knowledge gap in the function of BAFF and APRIL in MS and other immunemediated diseases. Anti-CD20 therapy, which reduces B cell numbers, is an effective therapy for MS. ${ }^{2,29}$ Blocking BAFF and APRIL also reduces $B$ cell numbers and reduces flares in lupus. $^{30,31}$ Therefore, it was rational to hypothesize that blocking BAFF and APRIL in MS would be an effective treatment strategy. Paradoxically, TACI-Fc worsened disease activity in patients with MS. ${ }^{4}$ The similarity between patients with $\mathrm{MS}$ and $\mathrm{BCMA}^{-/-}$mice in their therapeutic response to anti-CD20 and TACI-Fc warrants the use of these mice for better assessment of new therapies targeting B cells. Given the multiligand receptor interactions that occur with BAFF and APRIL signaling, it has been difficult to identify mechanisms behind the therapeutic disparities in anti-CD20 and TACI-Fc. Our study provides evidence that BCMA is critical in the therapeutic efficacies of anti-CD20 and TACI-Fc in neuroautoimmune disorders like MS.

\section{Acknowledgment}

The authors thank Dr. Loren Erickson (University of Virginia) for providing the $\mathrm{BCMA}^{-/-}$mice.

\section{Study Funding}

This study was supported by grants from the NMSS (RG-160207722), the NIH (R01AI137047 and R01EY027346), and Merck-KGaA awarded to R.C. Axtell and grants from the NIH (1R01 AI131624-01A1 and R21 AI142186-01), Weill Institute of Neurosciences and the Maisin Foundation awarded to S.S. Zamvil.

\section{Disclosure}

R.C. Axtell has consulted Roche, EMD Serono, and Biogen Idec and is on the advisory board for Progentec Diagnostics Inc. S.S. Zamvil is a Deputy Editor of Neurology: Neuroimmunology and Neuroinflammation. The other authors have nothing to disclose. Go to Neurology.org/NN for full disclosures.

\section{Publication History}

Received by Neurology: Neuroimmunology \& Neuroinflammation August 17, 2020. Accepted in final form December 21, 2020.

Appendix Authors

\begin{tabular}{|c|c|c|}
\hline Name & Location & Contribution \\
\hline $\begin{array}{l}\text { Gaurav } \\
\text { Kumar, PhD }\end{array}$ & $\begin{array}{l}\text { Oklahoma Medical } \\
\text { Research } \\
\text { Foundation }\end{array}$ & $\begin{array}{l}\text { Conceptualized, designed, and } \\
\text { executed experiments, } \\
\text { interpreted results, and wrote the } \\
\text { manuscript }\end{array}$ \\
\hline $\begin{array}{l}\text { Zahra } \\
\text { Maria, PhD }\end{array}$ & $\begin{array}{l}\text { Oklahoma Medical } \\
\text { Research } \\
\text { Foundation }\end{array}$ & $\begin{array}{l}\text { Conducted experiments and } \\
\text { edited the manuscript }\end{array}$ \\
\hline $\begin{array}{l}\text { Uday Kohli, } \\
\text { BA }\end{array}$ & $\begin{array}{l}\text { Oklahoma Medical } \\
\text { Research } \\
\text { Foundation }\end{array}$ & Conducted experiments \\
\hline $\begin{array}{l}\text { Agnieshka } \\
\text { Agasing, } \\
\text { PhD }\end{array}$ & $\begin{array}{l}\text { Oklahoma Medical } \\
\text { Research } \\
\text { Foundation }\end{array}$ & $\begin{array}{l}\text { Conducted experiments and } \\
\text { edited the manuscript }\end{array}$ \\
\hline $\begin{array}{l}\text { James L. } \\
\text { Quinn, PhD }\end{array}$ & $\begin{array}{l}\text { Oklahoma Medical } \\
\text { Research } \\
\text { Foundation }\end{array}$ & $\begin{array}{l}\text { Conducted experiments and } \\
\text { edited the manuscript }\end{array}$ \\
\hline $\begin{array}{l}\text { Rose M. Ko, } \\
\text { PhD }\end{array}$ & $\begin{array}{l}\text { Oklahoma Medical } \\
\text { Research } \\
\text { Foundation }\end{array}$ & $\begin{array}{l}\text { Conducted experiments and } \\
\text { edited the manuscript }\end{array}$ \\
\hline $\begin{array}{l}\text { Scott S. } \\
\text { Zamvil, MD, } \\
\text { PhD }\end{array}$ & $\begin{array}{l}\text { University of } \\
\text { California San } \\
\text { Francisco }\end{array}$ & $\begin{array}{l}\text { Provided input in the experimental } \\
\text { design and writing of the } \\
\text { manuscript }\end{array}$ \\
\hline $\begin{array}{l}\text { Robert C. } \\
\text { Axtell, PhD }\end{array}$ & $\begin{array}{l}\text { Oklahoma Medical } \\
\text { Research } \\
\text { Foundation }\end{array}$ & $\begin{array}{l}\text { Conceptualized, designed } \\
\text { experiments, interpreted results, } \\
\text { and wrote the manuscript }\end{array}$ \\
\hline
\end{tabular}




\section{References}

1. Frohman EM, Racke MK, Raine CS. Multiple sclerosis: the plaque and its pathogenesis. N Engl J Med 2006;354:942-955.

2. Hauser SL, Waubant E, Arnold DL, et al. B-cell depletion with rituximab in relapsing-remitting multiple sclerosis. N Engl J Med 2008;358:676-688.

3. Kappos L, Li D, Calabresi PA, et al. Ocrelizumab in relapsing-remitting multiple sclerosis: a phase 2, randomised, placebo-controlled, multicentre trial. Lancet 2011;378:1779-1787.

4. Kappos L, Hartung HP, Freedman MS, et al. Atacicept in multiple sclerosis (ATAMS): a randomised, placebo-controlled, double-blind, phase 2 trial. Lancet Neurol 2014;13:353-363.

5. Moore PA, Belvedere O, Orr A, et al. BLyS: member of the tumor necrosis factor family and B lymphocyte stimulator. Science 1999;285:260-263.

6. Schneider P, MacKay F, Steiner V, et al. BAFF, a novel ligand of the tumor necrosis factor family, stimulates B cell growth. J Exp Med 1999;189:1747-1756.

7. Stein JV, Lopez-Fraga M, Elustondo FA, et al. APRIL modulates B and T cell immunity. J Clin Invest 2002;109:1587-1598.

8. Mackay F, Schneider P, Rennert P, Browning J. BAFF and APRIL: a tutorial on B cell survival. Annu Rev Immunol 2003;21:231-264.

9. Gross JA, Johnston J, Mudri S, et al. TACI and BCMA are receptors for a TNF homologue implicated in B-cell autoimmune disease. Nature 2000;404:995-999.

10. Marsters SA, Yan M, Pitti RM, Haas PE, Dixit VM, Ashkenazi A. Interaction of the TNF homologues BLyS and APRIL with the TNF receptor homologues BCMA and TACI. Curr Biol 2000;10:785-788.

11. Shu HB, Johnson H. B cell maturation protein is a receptor for the tumor necrosis factor family member TALL-1. Proc Natl Acad Sci USA 2000;97:9156-9161.

12. Thompson JS, Bixler SA, Qian F, et al. BAFF-R, a newly identified TNF receptor that specifically interacts with BAFF. Science 2001;293:2108-2111.

13. Thompson JS, Schneider P, Kalled SL, et al. BAFF binds to the tumor necrosis factor receptor-like molecule $\mathrm{B}$ cell maturation antigen and is important for maintaining the peripheral B cell population. J Exp Med 2000;192:129-135.

14. Rennert P, Schneider P, Cachero TG, et al. A soluble form of B cell maturation antigen, a receptor for the tumor necrosis factor family member APRIL, inhibits tumor cell growth. J Exp Med 2000;192:1677-1684.

15. Yan M, Brady JR, Chan B, et al. Identification of a novel receptor for B lymphocyte stimulator that is mutated in a mouse strain with severe B cell deficiency. Curr Biol 2001;11:1547-1552.

16. Kim SS, Richman DP, Zamvil SS, Agius MA. Accelerated central nervous system autoimmunity in BAFF-receptor-deficient mice. J Neurol Sci 2011;306:9-15.

17. Carrillo-Ballesteros FJ, Oregon-Romero E, Franco-Topete RA, et al. B-cell activating factor receptor expression is associated with germinal center B-cell maintenance. Exp Ther Med 2019; 17:2053-2060.
18. Krumbholz M, Theil D, Derfuss T, et al. BAFF is produced by astrocytes and up regulated in multiple sclerosis lesions and primary central nervous system lymphoma. J Exp Med 2005;201:195-200.

19. Stohl W, Banfalvi A. B cell-independent contribution of BAFF to murine autoimmune disease. Clin Immunol 2016;172:111-116.

20. Xu S, Lam KP. B-cell maturation protein, which binds the tumor necrosis factor family members BAFF and APRIL, is dispensable for humoral immune responses. Mol Cell Biol 2001;21:4067-4074.

21. Yang M, Hase H, Legarda-Addison D, Varughese L, Seed B, Ting AT. B cell maturation antigen, the receptor for a proliferation-inducing ligand and $\mathrm{B}$ cell-activating factor of the TNF family, induces antigen presentation in B cells. J Immunol 2005;175:2814-2824.

22. Jiang C, Loo WM, Greenley EJ, Tung KS, Erickson LD. B cell maturation antigen deficiency exacerbates lymphoproliferation and autoimmunity in murine lupus. J Immunol 2011;186:6136-6147.

23. Matsushita T, Yanaba K, Bouaziz JD, Fujimoto M, Tedder TF. Regulatory B cells inhibit EAE initiation in mice while other B cells promote disease progression. J Clin Invest 2008;118:3420-3430.

24. Huntington ND, Tomioka R, Clavarino C, et al. A BAFF antagonist suppresses experimental autoimmune encephalomyelitis by targeting cell-mediated and humoral immune responses. Int Immunol 2006;18:1473-1485.

25. Gross JA, Dillon SR, Mudri S, et al. TACI-Ig neutralizes molecules critical for B cell development and autoimmune disease. impaired B cell maturation in mice lacking BLyS. Immunity 2001;15:289-302.

26. Zhang X, Park CS, Yoon SO, et al. BAFF supports human B cell differentiation in the lymphoid follicles through distinct receptors. Int Immunol 2005;17:779-788.

27. O'Connor BP, Raman VS, Erickson LD, et al. BCMA is essential for the survival of long-lived bone marrow plasma cells. J Exp Med 2004;199:91-98.

28. Ng LG, Sutherland AP, Newton R, et al. B cell-activating factor belonging to the TNF family (BAFF)-R is the principal BAFF receptor facilitating BAFF costimulation of circulating T and B cells. J Immunol 2004;173:807-817.

29. Hawker K, O'Connor P, Freedman MS, et al. Rituximab in patients with primary progressive multiple sclerosis: results of a randomized double-blind placebocontrolled multicenter trial. Ann Neurol 2009;66:460-471.

30. Dall'Era M, Chakravarty E, Wallace D, et al. Reduced B lymphocyte and immunoglobulin levels after atacicept treatment in patients with systemic lupus erythematosus: results of a multicenter, phase $\mathrm{Ib}$, double-blind, placebo-controlled, doseescalating trial. Arthritis Rheum 2007;56:4142-4150.

31. Isenberg D, Gordon C, Licu D, Copt S, Rossi CP, Wofsy D. Efficacy and safety of atacicept for prevention of flares in patients with moderate-to-severe systemic lupus erythematosus (SLE): 52-week data (APRIL-SLE randomised trial). Ann Rheum Dis 2015;74:2006-2015. 


\title{
Neurology \\ Neuroimmunology \& Neuroinflammation
}

\author{
CNS Autoimmune Responses in BCMA-Deficient Mice Provide Insight for the Failure \\ of Atacicept in MS \\ Gaurav Kumar, Zahra Maria, Uday Kohli, et al. \\ Neurol Neuroimmunol Neuroinflamm 2021;8; \\ DOI 10.1212/NXI.0000000000000973
}

This information is current as of March 1, 2021

Updated Information \&

Services

References

Citations

Subspecialty Collections

Permissions \& Licensing

Reprints including high resolution figures, can be found at:

http://nn.neurology.org/content/8/3/e973.full.html

This article cites 31 articles, 13 of which you can access for free at: http://nn.neurology.org/content/8/3/e973.full.html\#\#ref-list-1

This article has been cited by 1 HighWire-hosted articles: http://nn.neurology.org/content/8/3/e973.full.html\#\#otherarticles

This article, along with others on similar topics, appears in the following collection(s):

All Immunology

http://nn.neurology.org//cgi/collection/all_immunology

Autoimmune diseases

http://nn.neurology.org//cgi/collection/autoimmune_diseases

Multiple sclerosis

http://nn.neurology.org//cgi/collection/multiple_sclerosis

Information about reproducing this article in parts (figures,tables) or in its entirety can be found online at:

http://nn.neurology.org/misc/about.xhtml\#permissions

Information about ordering reprints can be found online:

http://nn.neurology.org/misc/addir.xhtml\#reprintsus

Neurol Neuroimmunol Neuroinflamm is an official journal of the American Academy of Neurology.

Published since April 2014, it is an open-access, online-only, continuous publication journal. Copyright

Copyright $\odot 2021$ The Author(s). Published by Wolters Kluwer Health, Inc. on behalf of the American

Academy of Neurology.. All rights reserved. Online ISSN: 2332-7812.

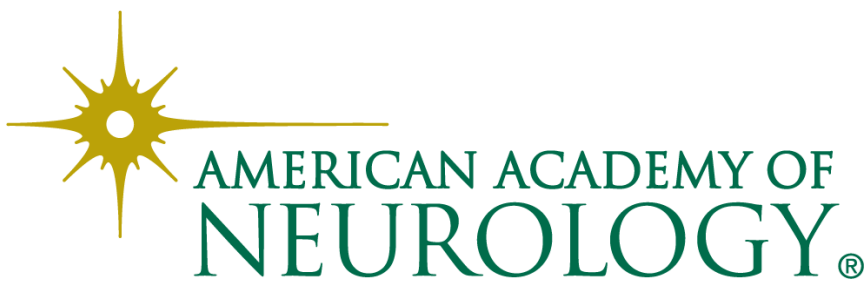

